\title{
CLOROPLAST PIGMENTS AS INDICATORS OF LEAD STRESS
}

\section{SILVÂNIA M. DE S. GOMES ${ }^{1}$, VERA LUCIA A. DE LIMA ${ }^{2}$, ADAILSON P. DE SOUZA ${ }^{3}$, JOAB J. V. R. DO NASCIMENTO ${ }^{4}$, EVERALDO S. DO NASCIMENTO ${ }^{5}$}

\begin{abstract}
Plants respond to environmental adversities, becoming an indicator for assessing the environment quality. In this aspect, chlorophyll contents as well, carotenoids are used as a reliable indicator to associate environmental quality and pollution, mainly regarding the toxicity of heavy metals in higher plants. So, we aimed to evaluate the content of chlorophyll $a$, b, and total chlorophylls and carotenoids in plants vetiver [Vetiveria zizanioides (L.) Nash], maize (Zea mays L.) cv. AG 1051, sunflower (Helianthus annuus L.) cv. BRS 122/V-2000, and castor beans (Ricinus communis L. ) cv . Northeastern BRS grown in contaminated soil with lead, with and without correction of soil $\mathrm{pH}$, so they were used as indicators of metal stress by the soil. From the biochemical point of view, the correction of soil $\mathrm{pH}$ values caused chlorophyll a, b and total statistically higher for vetiver species and castor beans in the analyzed periods, except for the analysis performed 60 days after transplanting where only the species vetiver benefited from the correction of soil $\mathrm{pH}$ on the content of chlorophyll $\mathrm{b}$ and total. On the other hand plants without correction of soil $\mathrm{pH}$ showed a decrease of all chlorophyll levels. In addition, the largest increase in the synthesis of carotenoids, indicated that under stress the plants have developed alternative routes of dissipation of energy in order to avoid problems of photo-inhibition and photo-oxidation.
\end{abstract}

KEYWORDS: heavy metal, pollution, photosynthesis.

\section{PIGMENTOS CLOROPLASTÍDEOS COMO INDICADORES DE ESTRESSE POR CHUMBO}

RESUMO: As plantas respondem às adversidades ambientais, constituindo-se num indicador para avaliar a qualidade do meio. Neste aspecto, os teores de clorofilas, bem como de carotenoides são usados como um indicador confiável para associar qualidade ambiental e poluição, principalmente, relacionando a toxicidade de metais pesados para plantas superiores. Para tanto, objetivou-se avaliar os teores de clorofilas a, b, clorofilas totais e carotenoides em plantas de vetiver [Vetiveria zizanioides (L.) Nash], milho (Zea mays L.) cv. AG 1051, girassol (Helianthus annuus L.) cv. BRS 122/V-2000, e mamona (Ricinus communis L.) cv. BRS nordestina, cultivadas em solo contaminado com chumbo, com e sem correção do pH do solo, de modo a utilizá-las como indicadores do nível de estresse pelo metal. Do ponto de vista bioquímico, a correção do pH do solo provocou valores de clorofila $\mathrm{a}, \mathrm{b}$ e total, estatisticamente superiores para as espécies vetiver e mamona, nos períodos analisados, com exceção da análise realizada aos 60 dias após o transplante das mudas onde apenas a espécie vetiver foi beneficiada pela correção do $\mathrm{pH}$ do solo para os teores de clorofila $\mathrm{b}$ e totais. Por outro lado, as plantas sem correção do $\mathrm{pH}$ do solo apresentaram diminuição de todos os teores de clorofila. Em adição, o maior incremento na síntese de carotenoides totais indicou que sob estresse as plantas desenvolveram rotas alternativas de dissipação de energia a fim de evitar problemas de fotoinibição e fotoxidação.

PALAVRAS-CHAVE: metal pesado, poluição, fotossíntese.

\footnotetext{
${ }^{1}$ Eng ${ }^{a}$ Agrônoma, Prof ${ }^{a}$. Dra ${ }^{a}$, Depto. de Agropecuária, UFPB /Bananeiras-PB, Fone: (83) 9902-4834, silvania.ufpb@ yahoo.com.br;

${ }^{2}$ Eng $^{\mathrm{a}}$ Agrícola, Prof ${ }^{\mathrm{a}}$. Dr ${ }^{\mathrm{a}}$, Unidade Acadêmica de Eng. Agrícola, UFCG/Campina Grande-PB, antuneslima@gmail.com;

${ }^{3}$ Eng $^{\circ}$ Agrônomo, Prof. Doutor, Departamento de Solos e Engenharia Rural, UFPB/Areia- PB, adailson.ufpb@ yahoo.com.br;

${ }^{4}$ Eng $^{\mathrm{o}}$ Ambiental, Prof. Mestre, IFPB/Picuí-PB, joabjosemar@ gmail.com,

${ }^{5}$ Eng ${ }^{\circ}$ Agrônomo, UFPB /Areia - PB, everaldosn@hotmail.com.

Recebido pelo Conselho Editorial em: 17-5-2013

Aprovado pelo Conselho Editorial em: 1-4-2014
}

Eng. Agríc., Jaboticabal, v.34, n.5, p. 877-884, set./out. 2014 


\section{INTRODUCTION}

The environment adversity, also understood as stress refers to a set of factors such as extreme temperatures, salinity, presence of metals, among others, exercising a disadvantageous influence on plant, which may present as genetic, metabolic, morphological and physiological mechanisms stable changes such as tolerance to these environments (TAIZ \& ZEIGER, 2013). These adjustments relate primarily to changes that come forward in plant leaves, as this organ is of rapid growth and constant renewal.

The contents of chlorophyll, as well as carotenoids are used as trusted indicators to associate environmental quality and pollution (PAULUS et al., 2010) and can be related to heavy metal toxicity to higher plants. On one side the chlorophyll are the main chloroplasts pigments responsible for collecting solar radiation which during the photosynthetic process is converted into chemical energy in the form of ATP and NADPH (TAIZ \& ZEIGER 2013) and on the other hand carotenoids are essential to photosynthesis acting as secondary pigments, pro-vitamin factor and sunscreen which eliminate free radicals such as ROS in damaged tissue (PANDY et al., 2010).

According to PEDRON et al. (2009) among the heavy metals, lead has been highlighted as a major environmental contaminants, especially for soil and water (GAUTAM et al, 2011; MEERS et al. 2010; FÄSSLER et al., 2010; ARAÚJO \& NASCIMENTO, 2010; NASCIMENTO \& XING, 2006) whose plant excess causes several symptoms of toxicity, such as growth reduction, chlorosis and darkening of the root system. Also inhibits photosynthesis, as a result of disruption of chloroplast organization, synthesis of chlorophyll, plastoquinone and carotenoids, blocking the transport of electrons, inhibiting the activity of Calvin cycle enzymes as well as CO2 deficiency as a result of the stomata closing (SHARM \& DUBEY, 2005) reducing production of phytomass. With regard to inhibition of chlorophyll synthesis, it has been suggested that in the presence of $\mathrm{Pb}$ (GAUTAM et al., 2011) occurs a reduction of the ALAD enzyme activity (5-Aminolevulinic Acid Dehydratase), which is considered the key enzyme in the route of chlorophyll synthesis.

Thus, knowing the importance of the photosynthetic process, to know which processes are affected by $\mathrm{Pb}$, can provide important data on the plant metabolism, thus becoming an important tool for selection of tolerant plants. So, we aimed to evaluate the content of chlorophyll a, b, and total chlorophyll and carotenoids in plants of vetiver [Vetiveria zizanioides (L.) Nash], maize (Zea mays L.) cv. AG 1051, sunflower (Helianthus annuus L.) cv. BRS 122/V-2000, and castor beans (Ricinus communis L.) cv. northeastern BRS grown in contaminated soil by $\mathrm{Pb}$, with and without correction, in order to use them as indicators of metal stress.

\section{MATERIAL AND METHODS}

The experiment was conducted in an area belonging to the industry METALS PB - LTD, which operates since 1996 in the business of recycling acid lead automotive batteries and is located at $\mathrm{km} 28$ of BR 101, municipality of Rio Tinto, PB, Brazil with geographic coordinates $06^{\circ} 43$ '51.2" south latitude and $35^{\circ} 07^{\prime} 17.1^{\prime \prime}$ longitude. It has an approximate altitude of 11 meters, with an average annual rainfall of about $1200 \mathrm{~mm}$ (AESA, 2011).

The experimental area was classified as HIDROMORPHY CARBIC SPODSOL (EMBRAPA, 2006), which was exposed to high concentrations of $\mathrm{Pb}$, due to deposition of byproducts of the recycling automotive batteries (trash and wastewater), whose granulometric and fertility characterization are shown in Table 1.

Plants of vetiver [Vetiveria zizanioides (L.) Nash], maize (Zea mays L.) cv. AG 1051, sunflower (Helianthus annuus L.) cv. BRS 122/V-2000, and castor beans (Ricinus communis L.) cv. northeastern BRS were used and were selected based on preliminary studies (ALVES et al., 2008) showing good prospects for phyto-extraction of $\mathrm{Pb}$ and for being species that combine reasonable accumulation of metals with high biomass production (VAMELARI et al., 2010). 
The sunflower and castor beans seedlings were grown from seeds in polythene bags using as substrate a mixture of sand and organic compost in 1:1 ratio, and standardized as a function of the first pair of definitive leaves, while vetiver were produced by clump tillering standardized according to their mass $( \pm 5 \mathrm{~g})$, and then transplanted into the experimental plots. Corn seeds were sown directly in the Field.

TABLE 1. Chemical and physical characterization of Spodosol contaminated by lead in Rio Tinto, PB.

\begin{tabular}{|c|c|}
\hline Characteristics & Value \\
\hline$\overline{\mathrm{pH}}$ (water 1:2.5) & 3.63 \\
\hline $\mathrm{Al}\left(\mathrm{cmol}_{\mathrm{c}} \mathrm{dm}^{-3}\right)$ & 0.80 \\
\hline $\mathrm{Ca}\left(\mathrm{cmol}_{\mathrm{c}} \mathrm{dm}^{-3}\right)$ & 0.65 \\
\hline $\mathrm{Mg}\left(\mathrm{cmol}_{\mathrm{c}} \mathrm{dm}^{-3}\right)$ & 0.57 \\
\hline$P\left(\mathrm{mg} \cdot \mathrm{dm}^{-3}\right)$ & 3.24 \\
\hline $\mathrm{K}\left(\mathrm{cmol}_{\mathrm{c}} \mathrm{dm}^{-3}\right)$ & 0.03 \\
\hline $\mathrm{Na}\left(\mathrm{cmol}_{\mathrm{c}} \mathrm{dm}^{-3}\right)$ & 0.27 \\
\hline $\mathrm{H}+\mathrm{Al}\left(\mathrm{cmol}_{\mathrm{c}} \mathrm{dm}^{-3}\right)$ & 5.06 \\
\hline C.O. $\left(\mathrm{g} \mathrm{kg}^{-1}\right)$ & 9.21 \\
\hline Total $\mathrm{Pb}\left(\mathrm{mg} \mathrm{dm}^{-3}\right) *$ & 1810.80 \\
\hline Sand $\left(\mathrm{g} \mathrm{kg}^{-1}\right)$ & 948 \\
\hline Silt $\left(\mathrm{g} \mathrm{kg}^{-1}\right)$ & 22 \\
\hline Clay $\left(\mathrm{g} \mathrm{kg}^{-1}\right)$ & 30 \\
\hline Soil density $\left(\mathrm{g} \mathrm{cm}^{-3}\right)$ & 1.64 \\
\hline Field capacity $\left(\mathrm{g} \mathrm{g}^{-1}\right)$ & 0.17 \\
\hline
\end{tabular}

The seedlings were transplanted to experimental plots with $15 \mathrm{~m}^{2}(5 \times 3 \mathrm{~m})$, adopting for sunflower and vetiver, a spacing of $0.5 \times 0.3 \mathrm{~m}$ (100 plants / plot), for corn $0.5 \times 02 \mathrm{~m}$ (150 plants / plot) and for castor beans spacing of $0.5 \times 1.0 \mathrm{~m}$ (30 plants / plot). Fertilization was performed as recommended by CAVALCANTE et al. (1998) and cultural practices whenever necessary as well as irrigation during the periods of peak demand.

At 60, 90 and 120 days after transplantation was performed the collect from 2 plants / plot to carry out the analysis. To determine the content of chlorophyll a, b, and total and carotenoids, it was collected $50 \mathrm{mg}$ of fresh leaf tissue without the midrib, removed from the middle part of two leaves per plant, placed in plastic bags and kept in a box with ice. Then the material was cut into small pieces, macerated with $10 \mathrm{ml}$ of acetone $80 \%$ (v/ v), covered with aluminum foil to prevent light incidence and centrifuged at $3000 \mathrm{rpm}$ for five minutes. After this period, a rate of $2 \mathrm{~mL}$ each were all collected to determine the absorbance in a spectrophotometer at 470, 647 and $663 \mathrm{~nm}$. The content of photosynthetic pigments were calculated according to ARNON (1949) and LICHTENTHALER (1987) equations and expressed in $\mathrm{mg} \mathrm{g}^{-1} \mathrm{FW}$ (fresh weight).

The experimental design was a randomized block with four replications. The treatments were arranged in a layout plot where the main plot was represented by the studied species (sunflower, castor beans, corn and vetiver) with and without soil $\mathrm{pH}$ correction (liming) and the sub-plot by harvest dates (60, 90 and 120 days after planting).

The results obtained were subjected to analysis of variance and comparison of means by Tukey test, with $\mathrm{P} \leq 0.05$. All statistical analyzes were performed using the SAEG software, version 9.1 (SAEG, 2007).

\section{RESULTS AND DISCUSSION}

From the biochemical point of view, the correction of $\mathrm{pH}$ of the contaminated soil caused values of chlorophyll a, b and total, statistically superior to castor beans and vetiver species in the analyzed periods, except at 60 days after transplantation where only the vetiver species has 
benefited with the correction for the contents of chlorophyll $\mathrm{b}$ and total. The absence of liming (soil $\mathrm{pH}$ correction) in very acidic soils, as in the case of the study area hampers the establishment of plants to be used in phytoextraction of $\mathrm{Pb}$ (PEDRON et al., 2009). In these environments, there is a high concentration of $\mathrm{Pb}, \mathrm{Mn}$ and $\mathrm{Al}$ in solution (GONZÁLES-ALCARAZ et al., 2011), which is potentially available and can lead to phytotoxicity problems and cause reduction in chlorophyll content, due to the Pb effects on the synthesis of chlorophyll (GUPTA et al., 2009). Furthermore, under conditions of low $\mathrm{pH}$, there is a reduction in nutrient availability to plants, which leads to lower their development. In extreme cases, the phytotoxicity of these elements can even result in death of the plant as observed in the sunflower at 90 DAP and corn at 120 DAP (Figures 4, 5 and 6).

At the end of the experiment the results of soil analysis subjected to correction with exception of $\mathrm{pH}, \mathrm{Mg}$ and $\mathrm{CO}$, showed no significant differences (probability <0.05) in the variables analyzed, namely: $\mathrm{pH} 4.6+0.4 ; \quad \mathrm{P} 2.74+-0.3 \quad \mathrm{mg} \quad \mathrm{dm}^{-3} ; \quad \mathrm{K} \quad 0.13 \quad+-0.03 \quad \mathrm{cmol}^{-3}$; $\mathrm{Na} 0.02+-0.02 \mathrm{cmol} \mathrm{dm}^{-3} ; \mathrm{H}+\mathrm{Al} 3.43+-0.5 \mathrm{cmol} \mathrm{dm}^{-3} ;$ Al $0.75+0.1 \mathrm{cmol} \mathrm{dm}^{-3}$; $\mathrm{Ca} 0.5+-0.05 \mathrm{cmol} \mathrm{dm}^{-3}$; Mg $1.65+-0.2 \mathrm{cmol} \mathrm{dm}^{-3}$; and $\mathrm{MO} 4.2+-1.2 \mathrm{~g} \mathrm{~kg}^{-1}$.

It was noted that plants without soil $\mathrm{pH}$ correction showed statistically lower values of all chlorophylls. The same results were not observed for the species of sunflower and corn at 60 DAPS where no effect of liming was observed.
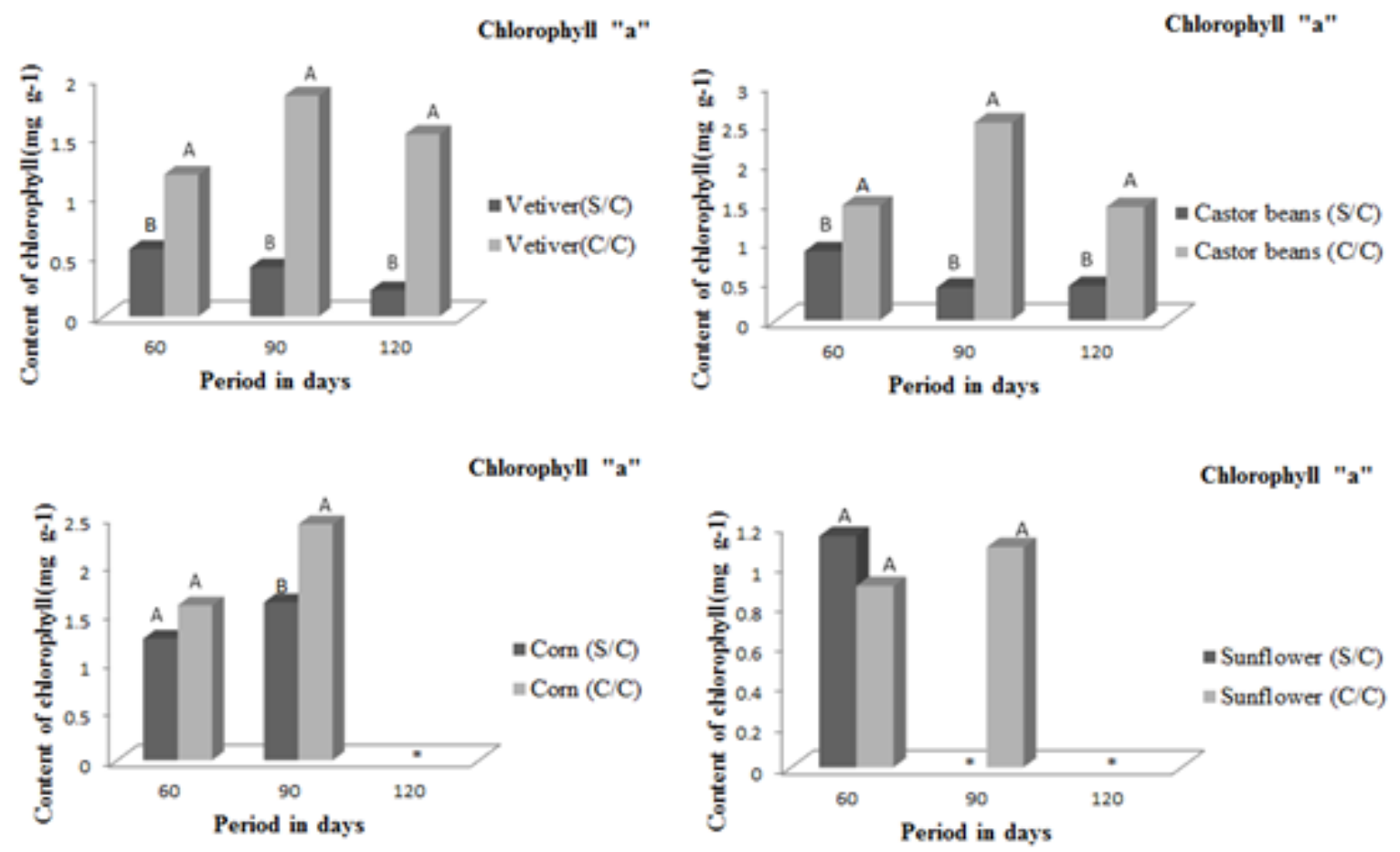

FIGURE 4. Content of chlorophyll a in plants of vetiver, castor beans, sunflower and corn conducted in contaminated soil, with and without correction, over the days after transplantation $(60,90$ and 120 DAP) (* Death of the plant).

Comparatively, at 90 DAP the average levels of chlorophyll a, b and total of the conducted species in contaminated soil with correction of soil $\mathrm{pH}$ (Figures 4, 5 and 6) were approximately 2 times higher than the value observed at 60 DAP, while an increase of only 1 time in relation to the initial value was observed for the species contaminated on uncorrected soil, in the same period. It can be assumed that under correction plants retain, in part, its ability to synthesize chlorophyll which according to LICHTENTHALER (1987), are constantly synthesized and deteriorated 
throughout its cycle, being its synthesis inhibited only in the presence of heavy metals as $\mathrm{Pb}$ (GUPTA et al. 2009).

Chlorophyll "b"

Chlorophyll "b"

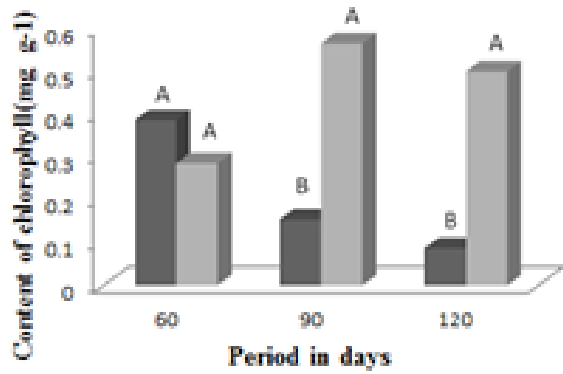

- Vetiver $(\mathrm{S} / \mathrm{C})$

$=$ Vetiver $(\mathrm{C} C \mathrm{C})$

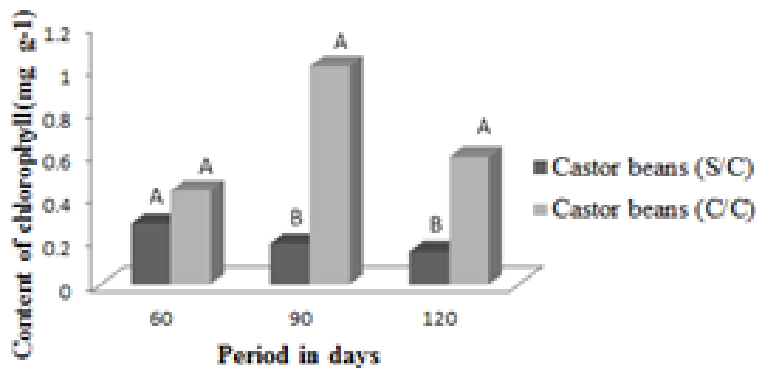

Chlorophyll "b"

Chlorophyll "b"
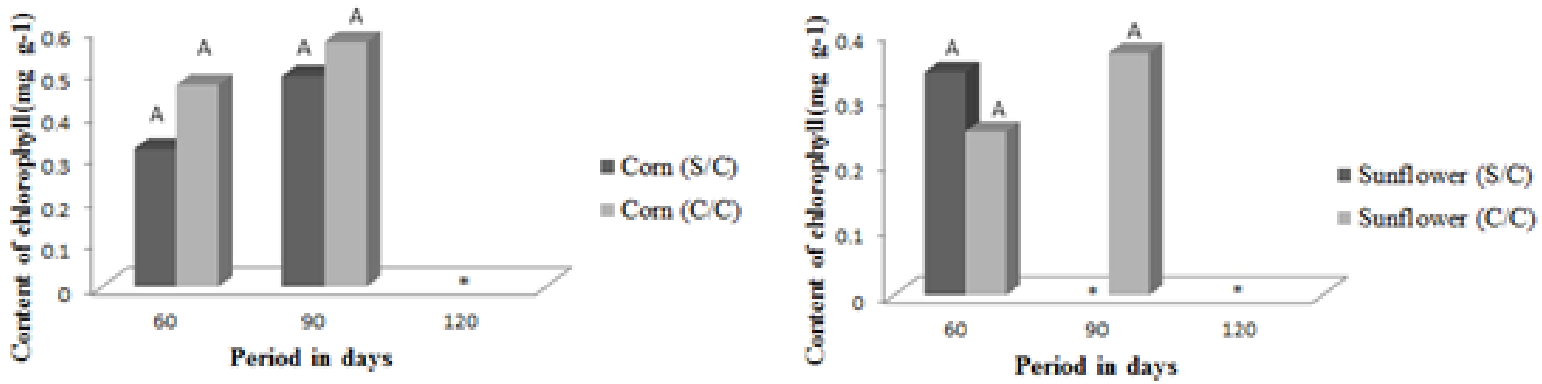

FIGURE 5. Content of chlorophyll $\mathrm{b}$ in plants of vetiver, castor beans, sunflower and corn conducted in contaminated soil, with and without correction, over the days after transplantation $(60,90$ and 120 DAP) (* Death of the plant).
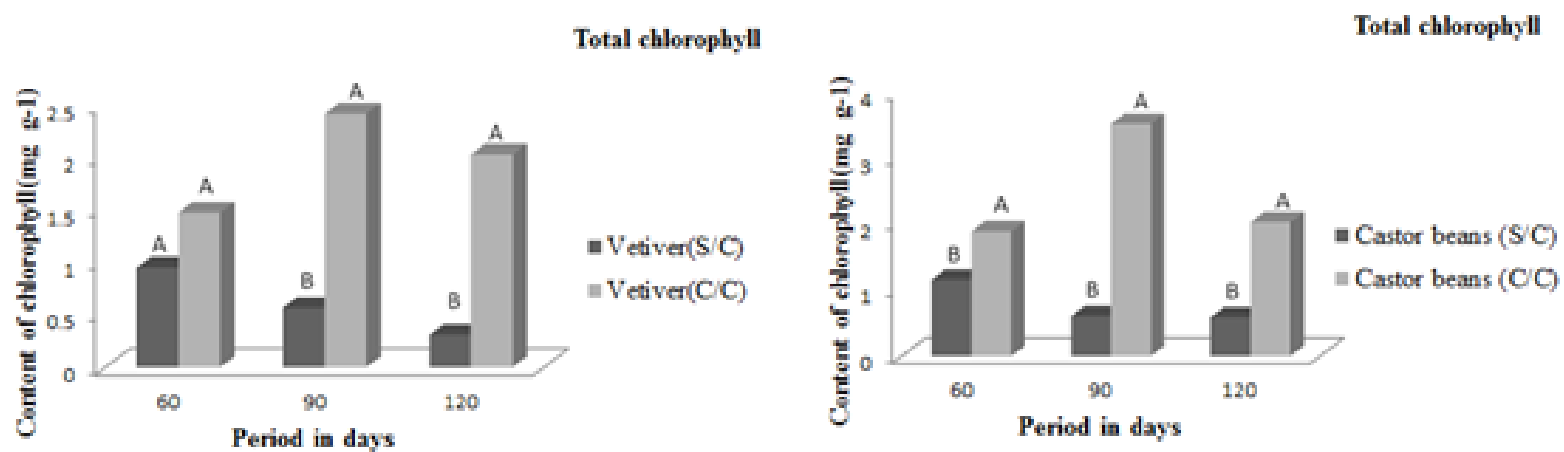

Total chlorophyll

Total chlorophyll
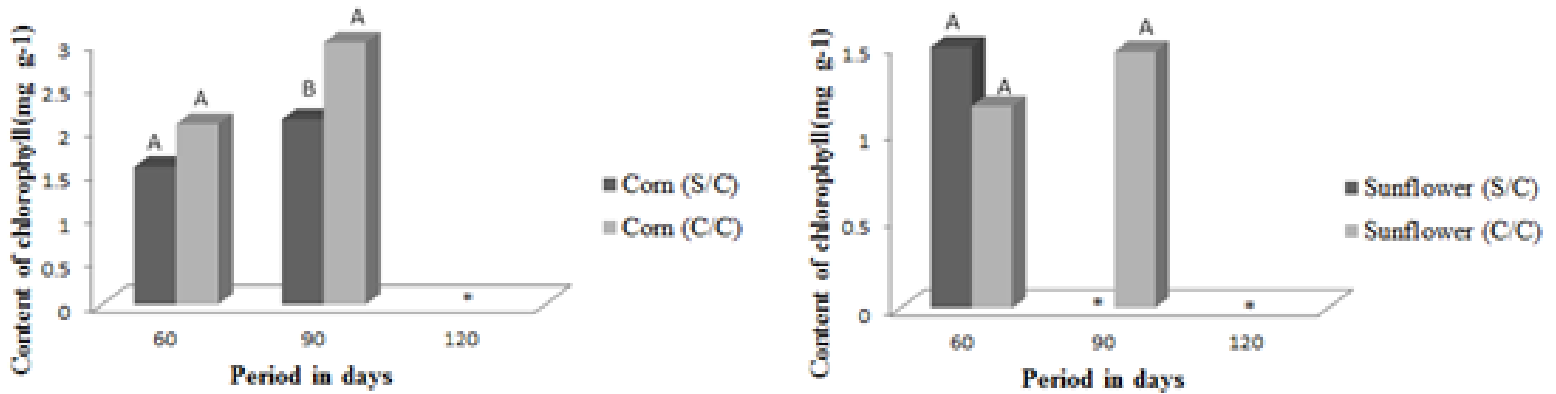

FIGURE 6. Content of total chlorophyll in plants of vetiver, castor beans, sunflower and corn conducted in contaminated soil, with and without correction, over the days after transplantation $(60,90$ and 120 DAP) (* Death of the plant). 
The inhibition begins with the substitution of $\mathrm{Pb}$ by the essential metal in the activation sites of many enzymes involved in the synthesis of chlorophyll also affecting according to GAUTAM et al. (2011) and AHMAD et al. (2011) both photochemical and carboxylation reactions. In seedlings of corn (Zea mays) exposed to different concentrations of $\mathrm{Pb}(25-200 \mu \mathrm{M})$ was observed decrease in activity of the enzyme $\delta$-aminolevulinic dehydrogenase (key enzyme in the synthesis of chlorophyll) (GUPTA et al, 2009). In addition, the determination of chlorophyll and carotenoids in the leaves can be used to diagnose the integrity of the photosynthetic apparatus in plants subjected to environmental adversities such as the heavy metals toxicity (DHIR et al, 2008; PAULUS et al 2010).

Therefore, the carotenoids are essential to photosynthesis acting as secondary pigments, provitamin factor and sunscreens that eliminate free radicals as ROS in damaged tissue (PANDEY et al., 2010; DHIR et al, 2008). The results of this study demonstrated significant effect on the soil correction contaminated with $\mathrm{Pb}$ on increasing concentration of carotenoids in leaves of vetiver, castor beans, sunflower and corn in the analyzed periods (Figure 7) when compared to soils without correction where there was a decrease concentration which according to NGAYILA et al. (2009) and WANG et al (2009) is an indicative of the stress induced by metals.
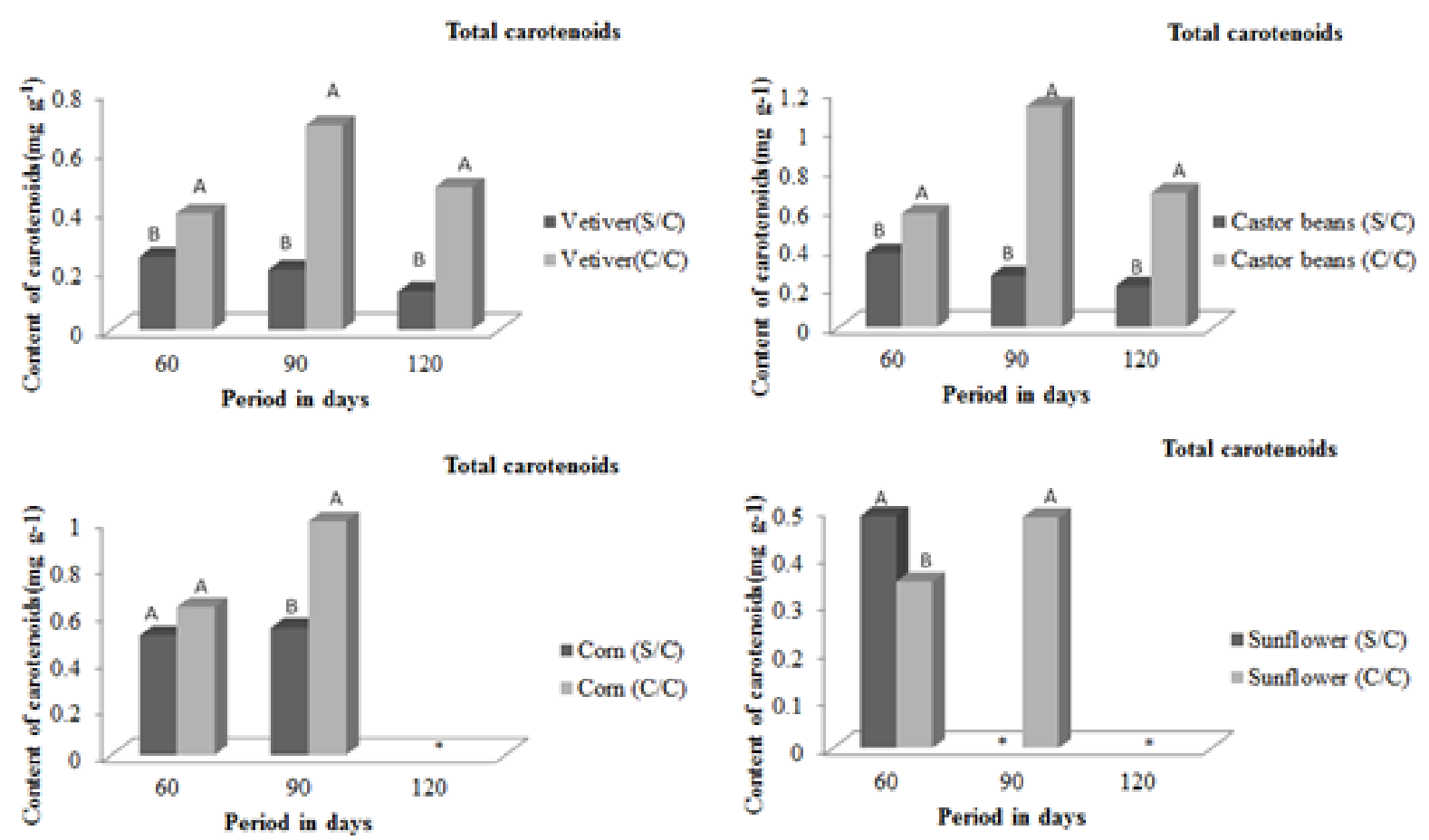

FIGURE 7. Carotenoid contents in plants of vetiver, castor beans, corn and sunflower conducted in contaminated soil, with and without correction, over the days after transplantation (60, 90 and 120 DAP) (* Death of the plant).

Carotenoids also act in cellular protection against photo-oxidative damage, which highlights the cycle of xanthophylls (violaxanthin, anteraxanthin and zeaxanthin) (PANDEY et al., 2010; DHIR et al., 2008). In relation to their antioxidant properties, carotenoids may act in several ways: reacting with products of lipid peroxidation interrupting the chain reaction; removing the singlet oxygen and dissipating the energy as heat; reacting with triplet chlorophyll or preventing the formation of singlet oxygen (FERREIRA et al., 2012).

The synthesis of chlorophyll $\mathrm{a}$ and $\mathrm{b}$ in plants under $\mathrm{Pb}$ stress on liming soil, occurred in parallel with increased levels of total carotenoids, suggesting that soil correction has favored species that maintained large capacity of absorption and transfer of luminous energy as well as thermal dissipation from energy excess (heat) via xanthophylls cycle. This is important because a loss of a 
thermal dissipation capacity, associated with an accumulation of ATP and NADPH in the stroma, could result in the direct reaction of electrons arising from photochemical phase of photosynthesis with molecular oxygen, resulting in a reversal of their spins, making it highly reactive (singlet oxygen) and may cause what is known as oxidative stress, which results ultimately in cell damage that can lead to plant death (PANDEY et al., 2010; DHIR et al, 2008). However, it is possible that the deviation from the normal route for the production of ATP and NADPH via reductase ferredoxin (Mehler reaction) results in the formation of superoxide radical, which is also highly reactive and may lead to other active oxygen species, such as chlorophyll triplet, hydroxyl radical and hydrogen peroxide (PEREIRA et al., 2012).

\section{CONCLUSIONS}

The correction of contaminated soil by lead promoted an increase in the synthesis of chlorophyll a, chlorophyll $\mathrm{b}$, total chlorophyll and carotenoids in species of vetiver, castor beans, sunflower and corn;

The chloroplast pigments are sensitive indicators to the levels of $\mathrm{Pb}$ in the soil;

The time at $90 \mathrm{DAP}$ is the period to improve response of the chloroplast pigments to the stress conditions by $\mathrm{Pb}$; and

There was a greater synthesis of total carotenoids in all species conducted under soil $\mathrm{pH}$ correction.

\section{REFERENCES}

AESA - Agência Executiva de Gestão das Águas do Estado da Paraíba - AESA. Pluviometria média do estado da Paraíba . 2006. Disponível em:<

http://www.aesa.pb.gov.br/geoprocessamento/geoportal/mapas.html> Acesso em: 23 maio 2011.

ARAÚJO, J.C.T.; NASCIMENTO, C.W.A. Phytoextraction of lead from soil from a battery recycling site: the use of citric acid and NTA. Water, Air and Soil Pollution, Dordrecht, v.211, p.113-120, 2010.

ARNON, D. J. Cooper enzymes in isolated chloroplast: Polyphenoloxidade in Beta vulgaris. Plant Physiology, Bethesda, v.24, p. 1-15,1949.

AHMAD, D. S. A.; ASHRAF, M.; TABASSAM, Q.; HUSSAIN, M.; FIRDOUS, H. Lead (Pb) Induced regulation of growth, photosynthesis, and mineral nutrition in maizene (Zea mays L) plants at early growth satges. Biological trace element research, Clifton, v. 144, n. 1-3, p. 1229-1239, 2011.

ALVES, J. C.; SOUZA, A. P.; PÔRTO, M. L.; ARRUDA, J. A.; TOMPSON JÚNIOR, U. A.; SILVA, G. B.; ARAÚJO, R. C.; SANTOS, D. Absorção e distribuição de chumbo em plantas de vetiver, jureminha e algaroba. Revista Brasileira de Ciência do Solo, Viçosa, MG, v. 32, p. 13291336, 2008.

CAVAlCANTE, F. J. A.; SANTOS, J. C. P.; PEREIRA, J. R.; LEITE, J. P.; SILVA, M. C. L.; FREIRE, F. J.; SILVA, D. J.; SOUSA, A. R.; MESSIAS, A. S.; FARIA, C. M. B.; BURGOS, N.; LIMA JÚNIOR, M. A.; GOMES, R. V.; CAVALCANTI, A. C.; LIMA, J. F. W. F. Recomendações de adubação para o estado de Pernambuco: $2^{\text {a }}$ aproximação. 2. ed. Recife: IPA, 1998. 198 p.

DHIR, B.; SHARMILA, P.; SARADHI, P.P. Photosynthetic performance of Salvinia Natans exposed to chromium and zinc rich wastewater. Brazilian Journal Plant Physiology, Piracicaba, v. 20, n.1, p. 61-70, 2008.

EMBRAPA - Empresa Brasileira de Pesquisa Agropecuária. Sistema brasileiro de classificação de solos. 2. ed. Rio de Janeiro: Embrapa Solos, 2006. 306 p. 
FÄSSLER, E.; ROBINSON, B. H.; STAUFFER, W.; GUPTA, S. K.; PAPRITZ, A.; SCHULIN, R. Phytomanagement of metal-contaminated agricultural land using sunflower, maize and tobacco. Agriculture, Ecosystems and Environment, Amsterdam, v. 136, p. 49-58, 2010.

GAUTAM, M.; SINGH, A. K.; JOHRI, R. M. Impacto f lead contaminated water on root morphology of tomato and brinjal. Indian Journal of Horticulture, Lucknow, v. 68, n. 4, p. $512-$ $515,2011$.

GUPTA, D. K., F. T. NICOLOSO, M. R. C. SCHETINGER, L. V. ROSSATO, L. B. PEREIRA, G. Y. CASTRO, S. SRIVASTAVA and R. D. Tripathi. Antioxidant defense mechanism in hydroponically grown Zea mays seedlings under moderate lead stress. Journal of Hazardous Materials, Amsterdam, v. 172, p. 479-484, 2009.

GONZÁLEZ-ALCARAZ, M. N.; CONESA, H. M.; TERCERO, M. C.; SCHULIN, R.; ÁLVAREZ-ROGEL, J.; EGEA, C. The combined use of liming and Sarcocornia fruticosa development for phyromanagement of salt marsh soils polluted by mine waste. Journal of Hazardous Materials, Amsterdam, v. 186, p. 805-813, 2011.

LICHTENTHALER, H.K. Chlorophylls and carotenoids: pigments of photosynthetic biomembranes. In: PACKER, L.; DOUCE, R. (Ed.) Methods in enzimology. London: Academic Press, 1987. v. 148, p. 350-381.

MEERS, E.; SLYCKEN, S. V.; ADRIAENSEN, K.; RUTTENS, A.; VANGROSVELD, J.; LAING, G. D.; WITTERS, N.; THEWYS, T.; TACK, F. M. G. The use of bio-energy crops (Zea mays) for 'phytoattenuation' of heavy metals on moderately contaminated soils: A field experiment. Chemosphere, Oxford, v.78, p. 35-41, 2010.

NASCIMENTO, C. W. A.; XING, B. Phytoextraction: a review on enhanced metal availability and plant accumulation. Scientia Agricola, Piracicaba, v. 63, n. 3, p. 299-311, 2006.

NGAYILA, N.; BOTINEAU, M.; BAUD, M.; BASLY, J. Myriophyllum alterniflorum: Effect of low concentrations of copper and cádmium on somatic and photosynthetic endpoints. $A$ chemometric approach, v. 9, n. 2, p. 307-312, 2009.

PANDEY, V.; DIXIT, V.; SHYAM, R. Chromium effect on ROS generation and detoxification in pea (Pisun sativum) leaf chloroplasts. Protoplasma, New York, v. 236, n. 1-4, p. 85-95, 2010.

PAULUS D; DOURADO NETO D.; FRIZZONE J. A.; SOARES T.M. Produção e indicadores fisiológicos de alface sob hidroponia com água salina. Horticultura Brasileira, Brasília, v. 28, p. 29-35, 2010.

PEDRON, F.; PETRUZZELLI, G.; BARBAFIERI, M.; TASSI, E. Strategies to use phytoextraction in very acidic soil contaminated by heavy metals. Chemosphere, Oxford, v. 75, p. 808-814, 2009.

PEREIRA, P. F.; ANTUNES, F.; BRAGA, V.F.; RESENDE, C. F.; RIBEIRO, C.; PEIXOTO, P. H. P. Pigmentos lipossolíveis e hidrossolúveis em plantas de Salvínio sob toxicidade por cromo.

Planta Daninha, Rio de Janiero, v. 30, n. 4, p. 397-703, 2012.

SAEG. Sistema para análises estatísticas. Versão 9.1. Viçosa: Fundação Arthur Bernardes, 2007.

SHARMA, P.; DUBEY, R.S. Lead toxity in plants. Brazilian Journal of Plant Physiology, Piracicaba, v. 17, n. 1, p. 35-52, 2005.

TAIZ, L.; ZEIGER, E. Fisiologia vegetal. 5 ed. Porto Alegre: Artmed, 2013.

VAMERALI, T.; BANDIERA, M.; MOSCA, G. Field crops for phytoremediation of metalcontaminated land. A review. Environmental Chemistry Letters, v. 8, Vitoria, p. 1-17, 2010.

WANG, H.; ZHAO, S. C.; LIU, R. L.; ZHOW, W.; JIN, J. Y. Changes of photosynthetic activities of maize (Zea mays L) seedlings in response to cadmim stress. Photosynthetica, Prague, v. 47, n. 277-283, 2009. 